Doroshenko 0. 0. [1; ORCID ID: 0000-0002-6428-0326], Ph.D., Associated Professor,

Pavliuk V. V. [1; ORCID ID: 0000-0002-2530-433X], master

${ }^{1}$ National University of Water and Environmental Engineering, Rivne

\title{
THE TRANSFORMATION OF THE ETHIC PRINCIPLES OF A PROFESSIONAL ACCOUNTANT UNDER THE INFLUENCE OF ARTIFICIAL INTELLIGENCE IN THE CONTEXT OF THE ECONOMIC THEORY OF HAPPINESS
}

The article is devoted to the analysis of the development of the principles of ethics of a professional accountant under the influence of the development of artificial intelligence in the context of the economic theory of happiness. The authors analyze the principles of professional ethics of an accountant in modern conditions and the features of their compliance with artificial intelligence. The features of transformation of professional requirements to a professional accountant under the influence of digital technologies are determined.

Keywords: artificial intelligence; professional accountant; The International Code of Ethics for Professional Accountants; integrity; objectivity; professional competence; due care; professional behavior; confidentiality; economic theory of happiness.

Formulation of scientific problem and its significance. The current state of economic development, its accelerated digitalization contributes to the search for new ideas, approaches, theories for further social trends. Strengthening the interconnection between different fields, close cross-links of economics, ecology, information systems, psychology lead to the development of integrated research areas. One of these areas is the economy of happiness, which, exploring the economic and non-economic subjective factors of well-being, focuses on the relationship between personal satisfaction, economic problems and quality of life.

In the ethical context, the economic theory of happiness is considered in the interdependence of its ethical and economic components, various forms of which are manifested in the influence of ethical imperatives on economic behavior and subjective demands on the content of pleasure and happiness in economics [1]. Continuing the interdisciplinary approach, we note that recently the society is actively advancing the idea that the development of modern digital technologies 
is displacing the profession of accountant from the labor market and each company will only need the appropriate software and its operator. Artificial intelligence has a significant impact on the world of accounting and finance. It can help accountants be more productive and efficient. Reducing by $80-90 \%$ the time required to complete the tasks will allow professionals to pay more attention to advising their clients, as well as reduce the number of errors.

Analysis of recent publications. More and more scientific works are devoted to the development of the accounting profession, its role in public life, principles of conduct of professional accountants and the role of artificial intelligence in the transformation of the responsibilities of an accountant, in particular, such scientists as Stalebrink O. J., Sacco J. F., Benson H., O'Leary T., Boland R. J. Jr., Greenwood E., Buckley J. W., Olson W. E., Dyachuk S. M., Dale Bye, Vitez O., Rezaee Z., Wang J., McKinney E., Yoos C., Snead K. etc. However, the rapid development of digital technologies, modern global phenomena which radically change approaches to all activities, generate new scientific discussions, and provide new arguments in favor of a particular opinion.

The purpose of the article is to study application features of the principles of ethics of a professional accountant in the conditions of the rapid development of artificial intelligence.

Presenting main material. Professional accountants all over the world play an important role in society. Investors, lenders, employers and the general public are users of economic information generated by professional accountants.

The professional attitude and behavior of professional accountants in providing such services affect the economic well-being of the entire country. Professional accountants will be able to remain in this privileged position only if they provide the public with their services at a high level, fully justifying the public confidence, because users of financial information rely on the objectivity of the data and the integrity of professional accountants in their business. That is why representatives of the accounting profession around the world are most interested in observing not only a high level of quality of work, but also ethical requirements, designed to provide this level. Given the need to establish these requirements, the International Federation of Accountants in 1998 adopted a Code of Ethics for Professional Accountants.

The need for a special code of ethics of accountants due to the specific content of the functions performed by accounting and the public purpose of the accounting profession. The organization's accounting as a single service of system accounting and control must be impeccable both for the organization's staff and for the company's partners. The 
accountant is obliged to objectively consider all emerging situations and real facts on matters within its competence. He must not allow personal bias, superstitions and pressure from the outside to affect the results of his activities.

Independence implies the ability of the accountant to act honestly and objectively: to reflect the true state of affairs of the organization, regardless of any conditions; to keep accounts and to form financial results.

A professional accountant is required to comply with the following fundamental principles:

1. Integrity is an important fundamental element of the accounting profession. Integrity requires accountants to be honest, candid and forthright with a client's financial information. Accountants should restrict themselves from personal gain or advantage using confidential information. While errors or differences in opinion regarding the applicability of accounting laws do exist, professional accountants should avoid the intentional opportunity to deceive and manipulate financial information [2]. An accountant should never stop short of obtaining all sufficient data to provide a reasonable foundation for his conclusions or recommendations.

2. Objectivity. A professional accountant should not allow bias, conflict of interest or undue influence of others to override professional or business judgments. Objectivity is important ethical value of the accounting profession. Accountants must remain free from conflicts of interest and other questionable business relationships when conducting accounting services. Objectivity governs an accountant's ability to work with integrity and independence [3].

3. Professional Competence and Due Care. Due care is the ethical value requiring accountants to observe all technical or ethical accounting standards. Due care requires accountants to exercise competence, diligence and a proper understanding of financial information [2]. A professional accountant has a continuing duty to maintain professional knowledge and skill at the level required to ensure that a client or employer receives competent professional service based on current developments in practice, legislation and techniques.

4. Confidentiality. A professional accountant should respect the confidentiality of information acquired as a result of professional and business relationships and should not disclose any such information to third parties without proper and specific authority unless there is a legal or professional right or duty to disclose.

5. Professional Behavior. A professional accountant should comply with relevant laws and regulations and should avoid any action that 
discredits the profession. This includes actions which a reasonable and informed third party, having knowledge of all relevant information, would conclude negatively affects the good reputation of the profession.

Effective business management largely depends on adherence to professional values, ethics and attitudes. Professional values, ethics and attitudes include commitment to technical competence, ethical behavior (independence, objectivity, confidentiality, honesty), professional attitude, striving for perfection and social responsibility, i.e. taking into account the interests of society.

In modern conditions, the profession of accountant is being transformed in every way under the influence of modern technology. Accountants use digital technology to improve their work. However, if we take into account the observance of $\mathrm{Al}$ accounting principles, then there are problems with this (table 1).

Table 1

The features of observance of ethical principles by professional accountants and artificial intelligence

\begin{tabular}{|c|c|c|}
\hline Principle & $\begin{array}{l}\text { Features of compliance by } \\
\text { professional accountants }\end{array}$ & $\begin{array}{c}\text { Features of compliance by } \\
\text { artificial intelligence }\end{array}$ \\
\hline Integrity & $\begin{array}{c}\text { Accountants should restrict } \\
\text { themselves from personal gain or } \\
\text { advantage using confidential } \\
\text { information. } \\
\text { Professional accountants must to } \\
\text { be straightforward and honest in } \\
\text { professional and business } \\
\text { relationships }\end{array}$ & \multirow{2}{*}{$\begin{array}{c}\text { Al is always honest because it is } \\
\text { created according to the } \\
\text { principles of integrity and } \\
\text { openness. Al cannot have a } \\
\text { subjective opinion and the need to } \\
\text { manipulate data on a particular } \\
\text { issue. }\end{array}$} \\
\hline Objectivity & $\begin{array}{l}\text { A professional accountant should } \\
\text { not allow bias, conflict of interest } \\
\text { or undue influence of others to } \\
\text { override professional or business } \\
\text { judgments }\end{array}$ & \\
\hline $\begin{array}{l}\text { Professional } \\
\text { Competence } \\
\text { and Due Care }\end{array}$ & $\begin{array}{l}\text { A professional accountant has a } \\
\text { continuing duty to maintain } \\
\text { professional knowledge and skill } \\
\text { at the level required to ensure } \\
\text { that a client or employer receives } \\
\text { competent professional service } \\
\text { based on current developments in } \\
\text { practice, legislation and } \\
\text { techniques }\end{array}$ & \multirow{2}{*}{$\begin{array}{l}\text { Compliance with this principle } \\
\text { depends on the speed of the } \\
\text { programmer who creates the } \\
\text { program, because new } \\
\text { requirements for accounting will } \\
\text { be included in the program at the } \\
\text { time of their publication, because } \\
\text { the program does not need to } \\
\text { learn and constant awareness } \\
\text { and understanding of relevant } \\
\text { technical and business } \\
\text { developments. } \\
\text { Al will also be capable of self- } \\
\text { learning and self-development }\end{array}$} \\
\hline $\begin{array}{l}\text { Professional } \\
\text { Behavior }\end{array}$ & $\begin{array}{l}\text { A professional accountant should } \\
\text { comply with relevant laws and } \\
\text { regulations; follow all the set } \\
\text { rules and regulations }\end{array}$ & \\
\hline
\end{tabular}


Continuation of Table 1

\begin{tabular}{|c|c|c|}
\hline & $\begin{array}{l}\text { this forces the accountant to } \\
\text { improve to meet the demands of } \\
\text { the times }\end{array}$ & \\
\hline Confidentiality & $\begin{array}{l}\text { Professional accountant is } \\
\text { obliged to strictly observe the } \\
\text { confidentiality of information } \\
\text { regarding the client's case in the } \\
\text { process of providing professional } \\
\text { services }\end{array}$ & $\begin{array}{l}\text { Al cannot guarantee the complete } \\
\text { confidentiality of information. } \\
\text { There are always risks of hacker } \\
\text { attacks. Information can be stolen } \\
\text { and can be used to cause harm, } \\
\text { financial loss or discrimination. } \\
\text { Developers or operators may } \\
\text { have access to the information }\end{array}$ \\
\hline
\end{tabular}

${ }^{*}$ developed by the authors

As for Integrity and Objectivity, Al has an advantage over man, because it cannot have a subjective opinion and the need to manipulate data on a particular issue, but it is not always an advantage. In some cases, honesty and integrity can be harmful, because the accountant, after analyzing the information, can express his opinion on the situation and suggest ways to improve. Al, in turn, can lead to negative information, which in turn will force the company to radically change some aspects.

As for the principle of Professional Competence and Due Care, its implementation depends on the speed of the person creating the program, because new requirements for accounting will be included in the program at the time of their publication, because the program does not need to learn and constant awareness and understanding of relevant technical and professional business developments.

As for privacy, the program may have a problem with this. After all, although Al is only a program, it always has a creator or people who control its work. Another problem may be the preservation of information, because information in our time can always be stolen, so the problem of data protection is still a problem.

But despite all the above facts, there is always the problem of objectivity of the program creator, because the program operates according to the algorithms that were created for it, and therefore is not protected from human influence. We should also not forget that there are more levers of influence on the program, because the problem of hacker attacks is more relevant than ever.

Conclusions. The accounting profession in the dimensions of the economy of happiness is very dynamic, constantly evolving and the main prerequisites and properties of such development, according to scientists are: theoretical knowledge, authority, public support, code of ethics, professional culture. In our opinion, this list should be 
supplemented by the property of «digital literacy», which is dictated by global trends in the global digitalization of all spheres of public life.

Summing up, we note that accounting in the context of business process automation is transformed for the better, and accountants become thorough analysts who create accounting and analytical support for management decisions, become financial analysts and auditors. The trend towards digitalization of business leads to a growing demand for professionals who know how to work in digital format. However, specialists with real emotions and personal highly professional attitude to the case, professional judgment, flexibility of thinking, focused on information requests of stakeholders will remain valuable. Therefore, in the development of technology, informatization and «digital economy» it is necessary to update the training programs for accounting and finance in the light of the requirements of the time, to develop professional development and retraining, which can not only form accounting (financial) statements also to be engaged in information support of administrative decisions.

1. Лавриненко В. М. Запити економічних смислів щастя. Вісник Академії праці $і$ соціальних відносин Федерації профспілок України, 2013. т.№ 3. С.56-60. 2. Osmond Vitez. Ethics in the Accounting Profession. URL: https://smallbusiness. chron.com /ethics-accounting-profession-3738.html (дата звернення: $01.09 .2021 \quad$ р.) 3. Professional accountants - the future: Drivers of change and future skills. URL: https://www.accaglobal.com/an/ en/technical-activities/technical-resourcessearch/2016/june/professional-accountants-the-future-report.html (дата звернення: 01.09.2021 p.) 4. Handbook Of The International Code Of Ethics For Professional Accountants. Internatonal Federation of Accountants. 2020 edition. URL: https://www.ifac.org/system/files/publications/files/IESBA-English-2020-IESBAHandbook_Web-LOCKED.pdf (дата звернення: 01.09 .2021 р.) 5. Handbook Of International Education Standards. Internatonal Federation of Accountants. 2019 edition. URL: https://www.ifac.org/system/files/publications/files/Handbook-ofInternational-Education-Standards-2019.pdf (дата звернення: 01.09.2021р.)

\section{REFERENCES:}

1. Lavrynenko V. M. Zapyty ekonomichnykh smysliv shchastia. Visnyk Akademii pratsi i sotsialnykh vidnosyn. Federatsii profspilok Ukrainy, 2013. т.№ 3. C.56-60. 2. Osmond Vitez. Ethics in the Accounting Profession. URL: https://smallbusiness. chron.com /ethics-accounting-profession-3738.html (accessed: 01.09.2021). 3. Professional accountants - the future: Drivers of change and future skills. URL: https://www.accaglobal.com/an/ en/technical-activities/technical-resourcessearch/2016/june/professional-accountants-the-future-report.html (accessed: 01.09.2021). 4. Handbook Of The International Code Of Ethics For Professional Accountants. Internatonal Federation of Accountants. 2020 edition. URL: https://www.ifac.org/system/files/publications/files/IESBA-English-2020-IESBA-

Handbook Web-LOCKED.pdf (accessed: 01.09.2021). 5. Handbook Of International 
Education Standards. Internatonal Federation of Accountants. 2019 edition. URL: https://www.ifac.org/system/files/publications/files/Handbook-of-InternationalEducation-Standards-2019.pdf (accessed: 01.09.2021).

Дорошенко О. О. [1; ORCID ID: 0000-0002-6428-0326],

к.е.н., доцент, Павлюк В. В. [1; ORCID ID: 0000-0002-2530-433X], магістр

${ }^{1}$ Національний університет водного господарства та природокористування, м. Рівне

\section{ТРАНСФОРМАЦІЯ ЕТИЧНИХ ПРИНЦИПІВ ПРОФЕСІЙНОГО БУХГАЛТЕРА ПІД ВПЛИВОМ ШТУЧНОГО ІНТЕЛЕКТУ В КОНТЕКСТІ ЕКОНОМІЧНОÏ ТЕОРІї ЩАСТЯ}

Стаття присвячена аналізу розвитку принципів етики професійного бухгалтера під впливом розвитку штучного інтелекту в контексті економічної теорії щастя. Автори констатують, що в етичному контексті економічна теорія щастя розглядається у взаємозалежності ії етичних і економічних складових, а це $є$ також важливою передумовою формування бухгалтерської професії. У той же час, великі можливості штучного інтелекту у бухгалтерській сфері викликані його головною перевагою здатністю обробляти величезні масиви інформації в найкоротші терміни. Це означає, що в перспективі Al зможе самостійно готувати різну звітність максимально швидко у порівнянні 3 бухгалтерами. Автори аналізують принципи професійної етики бухгалтера в сучасних умовах та особливості їх застосування за умови швидкого розвитку штучного інтелекту. Авторами досліджено специфіку дотримання принципів: доброчесності, об'єктивності, професійної компетентності та належної ретельності, конфіденційності, професійної поведінки. Автори дійшли висновку, що професія бухгалтера є дуже динамічною, постійно розвивається, і основними передумовами та властивостями такого розвитку $є$ : теоретичні знання, авторитет, суспільна підтримка, етичний кодекс, професійна культура, які в сучасних умовах варто доповнити властивістю «цифрової грамотності».

Бухгалтерський облік у контексті автоматизації бізнес-процесів трансформується на краще, а бухгалтери стають ґрунтовними аналітиками, які створюють обліково-аналітичне забезпечення управлінських рішень, стають фінансовими менеджерами та аудиторами. Тенденція до цифровізації бізнесу призводить до зростання попиту на професіоналів, які вміють працювати в цифровому форматі. Але цінними залишаться фахівці зі справжніми емоціями та особистим високопрофесійним ставленням до справи, професійним судженням, гнучкістю мислення, орієнтованим на інформаційні запити 
зацікавлених сторін. Тому в умовах розвитку технологій, інформатизації та «цифрової економіки» необхідно оновлювати навчальні програми бухгалтерського обліку та фінансів з урахуванням вимог часу, розвивати підвищення кваліфікації та перепідготовку кадрів, які можуть не тільки вести бухгалтерський облік та складати фінансову звітність, а й займатися інформаційним забезпеченням управлінських рішень.

Ключові слова: штучний інтелект; професійний бухгалтер; Міжнародний кодекс етики професійних бухгалтерів; чесність; об'єктивність; професійна компетентність; належна обережність; професійна поведінка; конфіденційність; економічна теорія щастя.

Дорошенко Е. А. [1; ORCID ID: 0000-0002-6428-0326], К.э.Н., доцент, Павлюк В. В. [1; ORCID ID: 0000-0002-2530-433X], магистр

${ }^{1}$ Национальный университет водного хозяйства и природопользования, г. Ровно

\section{ТРАНСФОРМАЦИЯ ЭТИЧЕСКИХ ПРИНЦИПОВ ПРОФЕССИОНАЛЬНОГО БУХГАЛТЕРА ПОД ВЛИЯНИЕМ ИСКУССТВЕННОГО ИНТЕЛЛЕКТА В КОНТЕКСТЕ ЭКОНОМИЧЕСКОЙ ТЕОРИИ СЧАСТЬЯ}

Статья посвящена анализу развития этических принципов профессионального бухгалтера под влиянием развития искусственного интеллекта в контексте экономической теории счастья. Авторы анализируют принципы профессиональной этики бухгалтера В современных условиях и особенности их применения при использовании искусственного интеллекта. Определены особенности трансформации профессиональных требований к профессиональному бухгалтеру под влиянием цифровых технологий.

Ключевые слова: искусственный интеллект; профессиональный бухгалтер; Международный кодекс этики профессиональных бухгалтеров; честность; объективность; профессиональная компетентность; надлежащая осторожность; профессиональное поведение; конфиденциальность; экономическая теория счастья. 